\title{
Food Commodity Development Strategies in Supporting Regional Food Security in Soppeng Regency
}

\author{
Fadilah Nurdin', Mahyuddin², Rahmadanih², Didi Rukmana², Saadah², Nurjannah Hamid ${ }^{3}$ \\ ${ }^{1}$ Agribusiness Study Program Students, Postgraduate School of Hasanuddin University, Makassar, 90245, Indonesia. \\ ${ }^{2}$ Lecturer of Agribusiness Program, Postgraduate School of Hasanuddin University, Makassar, 90245, Indonesia. \\ ${ }^{3}$ Lecturer of Managemen Department of Hasanuddin University, Makassar, 90245, Indonesia.
}

Correspondence Author: Fadilah Nurdin, Agribusiness Study Program Students, Postgraduate School of Hasanuddin University, Indonesia Email: fadilahnurdin@pasca.unhas.ac.id

Received date: 29 August 2019, Accepted date: 28 October 2019, Online date: 30 October 2019

Copyright: (C) 2019 Fadilah Nurdin., This is an open-access article distributed under the terms of the Creative Commons Attribution License, which permits unrestricted use, distribution, and reproduction in any medium, provided the original author and source are credited.

\begin{abstract}
This study aims to identify strategic food commodities in Soppeng Regency, analyze alternative food commodity development strategies to support regional food security in Soppeng Regency by analyzing internal and external conditions in formulating strategies for developing food commodities in Soppeng Regency. The method used in this research is descriptive analysis, IFE and EFE and SWOT analysis. The results of the analysis showed that based on food security analysis in Soppeng District, the indicated vulnerable district was Ganra District (Priority 1) with corn as a strategic food commodity that needed to be developed. Based on the SWOT analysis there are 8 alternative strategies in developing corn commodities in Soppeng Regency, namely: 1. Increasing production through expansion of corn planting areas, 2. Developing marketing areas, 3. Conducting farmers and extension workers for corn cultivation and processing, 4. Increasing farming capital farmers, 5 . Improving farmers' skills and knowledge, 6. Optimizing maize production through the application of technology and pest control, 7. Doing good cooperation with farmers, extension workers, input suppliers and home industries, 8. Strengthening government policies on fixing basic prices, agricultural machinery and production facilities.
\end{abstract}

Keywords: Food Commodities, Strategy Development, Corn, Food Security.

\section{INTRODUCTION}

Food security has an extensive dimension and involves many development sectors. The success of food security development is largely determined not only by the performance of one sector but also by other sectors. Thus the synergy between sectors, the synergy of government and society (including the business world) is the key to the success of the development of food security.

Government Regulation No. 17 of 2015 concerning Food and Nutrition Security Article 75 mandates the Government and Regional Governments following their authorities the obligation to build, compile and develop an integrated Food and Nutrition Information System, which can be used for planning, monitoring and evaluation, stabilizing food supply and prices as well as early warning system for food problems and food and nutrition insecurity. Government regulations are also mentioned in the framework of equitable distribution of food availability to all regions through the distribution of food through efforts to develop a food distribution system that is efficient, can maintain food safety, quality and nutrition as well as ensure the safety of food distribution. [1]

Based on the composite food insecurity map, Soppeng Regency is very resistant to food insecurity although on average it is perfect there are still areas with low composite scores. One effort that can be done to improve regional food security and the development of agribusiness simultaneously is the development of regional leading food commodities. The resilience of the agricultural sector is directed at domestic resource-based agricultural businesses (regional superior) whose product demand is not elastic to income or prices, so it is resilient in the face of economic turmoil. With the development of an agribusiness system, it can accommodate the goal of increasing product competitiveness [2]. In addition, relatively stable agricultural production has broad sectoral links and is very important for strengthening food security. Thus, this study aims to identify regional strategic food commodities as a basis for developing strategies to improve food security based on leading commodities. 


\section{RESEARCH METHODS}

This research is a descriptive study using a qualitative approach to determine strategic food commodities with secondary and qualitative data with the focus of analysis compiling alternative strategies which are priorities to be implemented.

This study uses key informants or certain social situations that are following the focus of the study to select key informants carried out deliberately (purposive sampling). Qualitative research is more focused on the representation of social phenomena so that the most critical sampling procedure is to determine key informants or certain social situations that are in accordance with the focus of research to select key informants carried out by purposive sampling. [3]

The key informants in this study were the Soppeng District Food Security Midwife and the agriculture instructor. the concept relating to informants is how to choose informants or certain social situations that can provide steady and reliable information about existing elements [4]. Furthermore, key informants appoint other informants who are considered to know a lot and master the problem under investigation and so on and will end if no more varied information is found from other informants [5]. This informant will later provide information on internal and external factors in the development of leading food commodities in Soppeng Regency. Then conducted with in-depth interviews with predetermined informants. The data obtained are primary and secondary data which are processed by quantitative and qualitative methods. In this study, the analysis that will be used is descriptive analysis and IFE analysis, EFE and SWOT analysis.

\section{RESULTS AND DISCUSSION}

A. Strategic Food Commodities in Soppeng Regency

Based on the analysis of composite food security, sub-districts in Soppeng Regency are listed in Priority 6 or are indicated to be very resistant to food and nutrition insecurity as reported by the gradation of dark green on the food security and vulnerability map. Even so, if you look at each individual indicator, there are still a number of districts that are indicated to be very vulnerable to food insecurity (Priority 1), showed to be vulnerable to food insecurity (Priority 2), and pointed to be somewhat susceptible to food insecurity (Priority 3).

Districts that are indicated vulnerable in Soppeng District are Ganra District (Priority 1) with a composite score of -2.12 . The food plants cultivated in the District of Ganra are Rice and Corn. Rice commodity is a superior regional commodity in Soppeng Regency. Based on the results of interviews with agricultural instructors that: "In addition to rice commodities which are the leading commodities in the Soppeng Regency, food crops that need more attention are corn commodities which also have the potential to be developed."

B. Analysis of Corn Agribusiness Development Potential

1. Land and Production Facilities

a. Certified Seedlings

Choosing the right seeds can make it easier to care for and provide an abundant harvest. The corn seedlings used by farmers namely Bisi 18, according to him, these seeds are suitable with the condition of the soil.

b. Land Potential for Corn Development

The large potential land area for corn development is an opportunity that needs to be cultivated to increase the total planting area of corn. Most farmers have switched from cocoa plantations to corn food crops.

c. Agricultural machine tools are limited

The availability of farming equipment and machinery needed is available at several nearby shops but is constrained due to costs, as well as the expensive wheel. As for what is difficult for farmers to obtain, they are spare parts.

d. Water availability

Water is no longer a problem faced by farmers in planting corn, with the correct pumping and irrigation and water security, the community is now able to plant corn 2 to 3 times a year.

e. Government Support

Government assistance in the tangible form is always given in the form of certified superior seeds. This was done in order to realize sustainable corn production.

f. Farmer's Capital

The capital used by farmers is their own capital. If the farmer's lack of capital sometimes reduces the number of inputs needed in his corn cultivation.

g. Weather and Climate

The problem for farmers is that in the rainy season when high rainfall causes river water to overflow and floods occur which results in farmers' corn being damaged and even failing to harvest.

h. The price of production facilities is relatively expensive

Means of agricultural production is a necessity that is used in aquaculture. These include seeds, fertilizers, pesticides and agricultural equipment. Agricultural production facilities in Soppeng Regency are generally sold at existing farm shops. In Soppeng agricultural production facilities have become relatively expensive including agricultural equipment and machinery. 
i. Management

To achieve the required high efficiency in the business, integrated business management from upstream to downstream and oriented agribusiness with partnerships will provide a reasonable profit on an ongoing basis [6]. Management planning and farm application costs that have not been coordinated. Can be seen for family labor, even though the family system is not paid but takes longer to wait because there is free time. For daily labor outside the family, you can buy more time and spend a lot of money. This situation can make the management of farming is less good. Daily wages in the area are Rp.50,000. For example, in one-hectare piece wages of Rp. 700,000, can be completed in 3 to 4 days. If using daily labor, the fastest for 4 days and at least 4 workers, so the costs incurred by farmers is Rp. 800,000.

2. Production

a. Ease of Plant Cultivation

The ease of cultivation and maintenance of corn is a factor that greatly affects the willingness of farmers to want to grow corn and want to expand the planting area.

b. Age of Maize Harvesting

The fast age of corn harvest (compared to other crops) around 100 days until it is ready to harvest is one of the factors that influence farmers to choose to grow corn.

c. Plant Pests (OPT)

The most common plant-disturbing organisms found in the corn farming community are the armyworm, leafhoppers, green aphids and others.

d. Farming Experience

The length of time a farmer does farming, especially corn, will determine the extent of the experience and knowledge of a farmer. Many farmers have experienced corn farming for up to 15 years, some informants from farmers selected by researchers also on average have quite a long farming experience. One informant who is now 45 years old, said that since childhood he had learned how to cultivate corn. Of course, farming experience gained by these farmers makes corn farming an inseparable part of life.

3. Processing

a. Maize Processing Household Industry

Home industries made from corn are still few and underdeveloped. This is due to the fact that on average the industry is still managed on a small scale and individually with its own capital. They did not dare to develop their business on a large scale because they were afraid of losing money. To find a capital loan is still in doubt. Some of the efforts that have been made are providing training to them on business development and offering to participate in exhibitions that are often held by local governments. But still, there were those who did not attend the event. consumers today were increasingly demanding high quality, cheap and fast delivery product [7].

4. Marketing

a. Regional Trade

In Soppeng Regency there are many markets used by farmers to process corn transactions. As in the central market, Takalala and Cabbenge markets. But most farmers sell their corn farms to collectors who come directly to the local farmers. One way to develop a business is to market share by increasing the network to various regions so that it is necessary to improve communication with relevant institutions and form and develop a nursery business [8]. Regarding post-harvest and marketing systems, farmers need business partners who guarantee capital, and marketing skills [9]. The partnership is a system of alliances that include various agribusiness activities ranging from pre-production and production to marketing [10].

b. High Market Demand

Market demand for corn is very high. In addition to animal feed also for large-scale processing industries. The feed is a significant component for the success of the cattle business [11]. This is known from the demand for corn to farmers and collectors who are experiencing an increase every year.

c. The bargaining position of farmers in setting selling prices

In determining the price of farmers as recipients of prices while traders as a determinant of prices so that it affects the weak bargaining position of farmers in setting selling prices and is felt by farmers.

5. Supporting Institutions

a. Quality of Agricultural Extension Workers

The length of experience of extension workers and education is expected to increase understanding and information obtained by farmers. Even so, the instructor's performance was not considered to be too good because the farmers' complaints were considered not yet conveyed to the local government.

\section{IFE and EFE Matrix}


The internal environment is an environment that consists of strength and weakness variables in the company's management control. Identifying internal factors can give a description of a company's condition, namely strength and weakness factors [12]. The IFE and EFE matrices can be seen in the following table.

Table 1. Internal Factor Evaluation Matrix (IFE) of Corn Agribusiness Development in Soppeng Regency.

\begin{tabular}{|c|c|c|c|}
\hline Internal Factors & Bobot & Rating & Bobot x Rating \\
\hline 1 & 2 & 3 & $4=2 \times 3$ \\
\hline \multicolumn{4}{|c|}{ Strenghs } \\
\hline \multicolumn{4}{|c|}{ Upstream Agribusiness Subsystem } \\
\hline 1. Certified Seedlings & 0.12 & 5.00 & 0.59 \\
\hline 2. Land Potential for Corn Development & 0.10 & 4.00 & 0.39 \\
\hline \multicolumn{4}{|c|}{ Production Subsystem } \\
\hline 3. Ease of Plant Cultivation & 0.10 & 3.00 & 0.29 \\
\hline 4. Age of Maize Harvesting & 0.10 & 3.00 & 0.29 \\
\hline 5. Business Experience & 0.12 & 4.00 & 0.47 \\
\hline Total Strength & 0.54 & & 2.03 \\
\hline \multirow{2}{*}{\multicolumn{4}{|c|}{$\begin{array}{c}\text { Weakness } \\
\text { Upstream Agribusiness Subsystem }\end{array}$}} \\
\hline & & & \\
\hline 1. Farmer's Capital & 0.10 & 2.50 & 0.25 \\
\hline 2. Management & 0.08 & 2.00 & 0.16 \\
\hline \multicolumn{4}{|c|}{ Downstream Agribusiness Subsystem } \\
\hline 3. Maize Processing Household Industry & 0.08 & 2.00 & 0.16 \\
\hline \multicolumn{4}{|c|}{ Agricultural Product Marketing Subsystem } \\
\hline 4. Farmers' Bargaining Position in Setting the & 0.12 & 2.00 & 0.24 \\
\hline \multicolumn{4}{|c|}{ Supporting institutions subsystem } \\
\hline 5. Quality of Agricultural Extension Workers & 0.10 & 2.50 & 0.25 \\
\hline Total Weaknesses & 0.48 & & 1.06 \\
\hline Total & 1 & & 3.09 \\
\hline
\end{tabular}

Source: Primary Data After Processing, 2019.

Table 2. External Factor Evaluation Matrix (EFE) for Corn Agribusiness Development in Soppeng Regency

\begin{tabular}{|c|c|c|c|}
\hline External Factors & Bobot & Rating & Bobot x Rating \\
\hline 1 & 2 & 3 & $4=2 \times 3$ \\
\hline \multicolumn{4}{|l|}{ Opportunities } \\
\hline \multicolumn{4}{|c|}{ Upstream Agribusiness Subsystem } \\
\hline 1. Water availability & 0.16 & 4.00 & 0.65 \\
\hline \multicolumn{4}{|c|}{ Downstream Agribusiness Subsystem } \\
\hline 2. Regional Trade & 0.14 & 3.50 & 0.47 \\
\hline 3. High Market Demand & 0.16 & 4.00 & 0.65 \\
\hline \multicolumn{4}{|c|}{ Supporting institutions subsystem } \\
\hline 4. Government Support & 0.14 & 3.00 & 0.41 \\
\hline Total Opportunities & 0.60 & & 2.18 \\
\hline \multirow{2}{*}{\multicolumn{4}{|c|}{$\begin{array}{c}\text { Treaths } \\
\text { Upstream Agribusiness Subsystem }\end{array}$}} \\
\hline & & & \\
\hline 1. Agricultural machine tools are limited & 0.08 & 1.50 & 0.12 \\
\hline 2. The price of production facilities is relatively expensive & 0.11 & 1.50 & 0.16 \\
\hline \multicolumn{4}{|c|}{ Downstream Agribusiness Subsystem } \\
\hline 3. Plant Pests (OPT) & 0.11 & 2.00 & 0.22 \\
\hline 4. Weather and Climate & 0.11 & 1.80 & 0.19 \\
\hline Total Threats & 0.41 & & 0.69 \\
\hline Total & 1 & & 2.87 \\
\hline
\end{tabular}

Source: Primary Data After Processing, 2019. 
D. Internal and External Matrices (IE)



4

4

3.5

25

(5)

.
3.5

$\begin{array}{llllll}3 & 2.5 & 2 & 1.5 & 1\end{array}$

Total Bobot Skor IFE

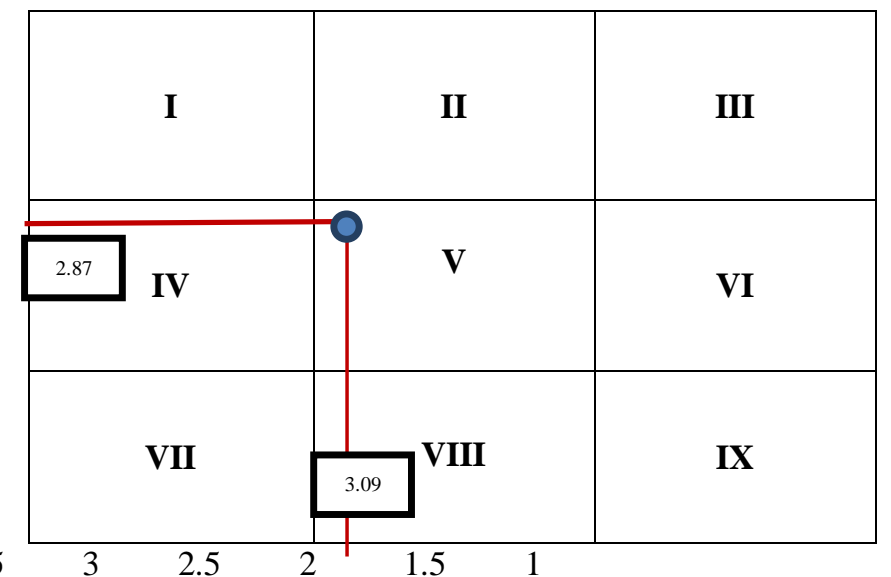

Figure 1. IE Matrix (Internal - External) Corn Development in

Soppeng Regency.

The results of the IE matrix show that the position of corn development in Soppeng Regency is in cell V in the IE matrix. The strategy cell shows the strategy that should be carried out, namely maintaining and maintaining (hold strategies). This shows that the most feasible strategy is market penetration strategy and product development.

\section{Table 3. SWOT Matrix of Corn Development in Soppeng Regency}

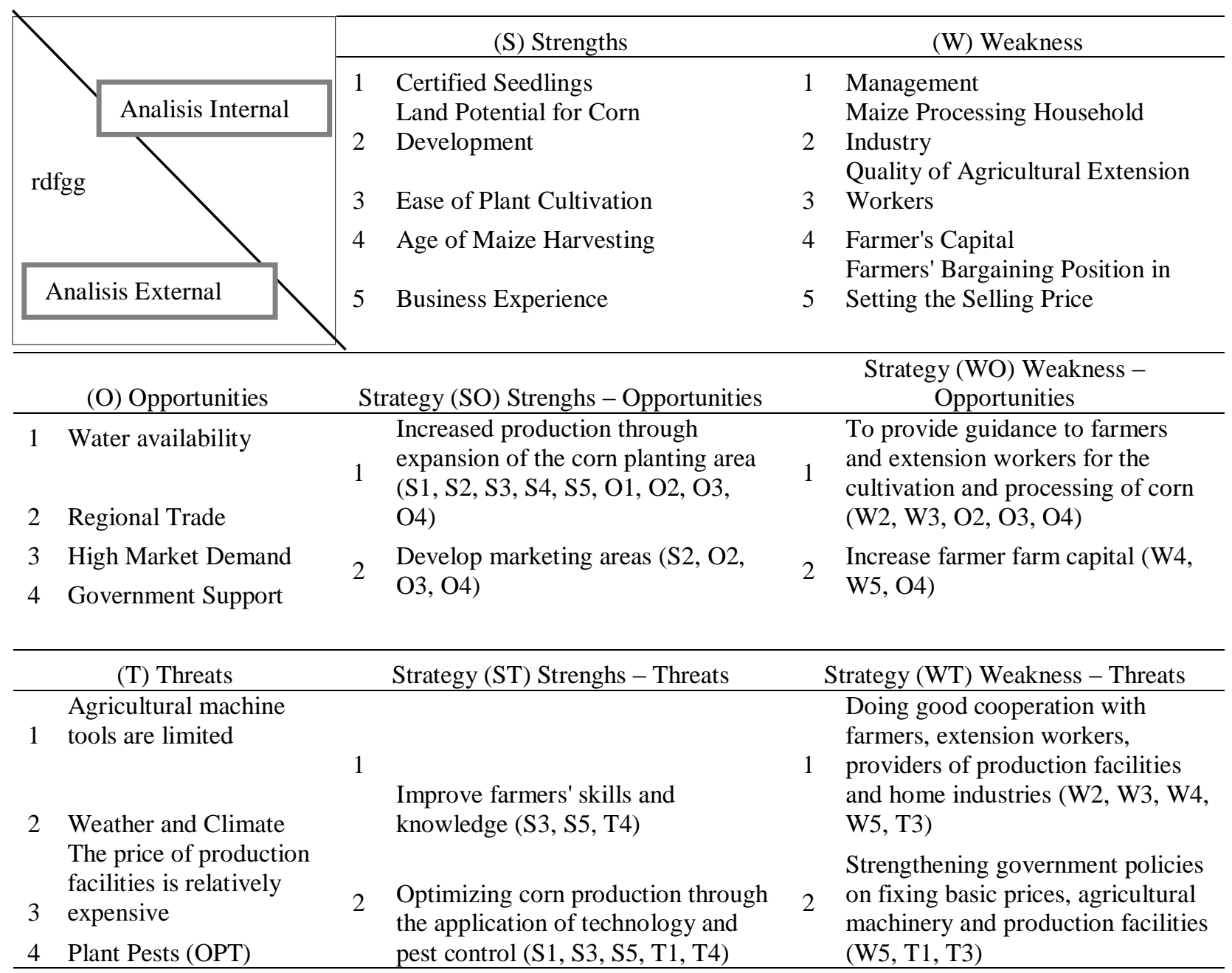

Source: Primary Data After Processing, 2019. 


\section{CONCLUSION}

Corn commodity is a food commodity that needs to be developed in Soppeng Regency. Based on the SWOT analysis there are 8 alternative strategies in developing corn commodities in Soppeng Regency, namely: 1. Increasing production through expansion of corn planting areas, 2. Developing marketing areas, 3. Conducting farmers and extension workers for corn cultivation and processing, 4. Increasing farming capital farmers, 5. Improving farmers' skills and knowledge 6. Optimizing maize production through the application of technology and pest control, 7. Doing good cooperation with farmers, extension workers, input suppliers and home industries, 8. Strengthening government policies on fixing basic prices, agricultural machinery and production facilities.

\section{REFERENCES}

[1] Badan Ketahanan Pangan. 2018. Peta Ketahanan dan Kerentangan Pangan. Kementrian Pertanian.

[2] Sirajuddin, S. N., Siregar, A. R., Nurlaelah, Lestari, V.S. 2017. The limitation and benefits of partnership sharing system of Coorporated Cattle Market (CCM). American-Eurasian Journal of Sustainable Agriculture, 11(1), 11-15.

[3] Bungin. 2009. Penelitian Kuantitatif dan Kualitatif. PT Bumi Aksara. Jakarta.

[4] Faisal, 2010. Penentuan Informan Penelitian. Raja Grafindo Persada. Jakarta.

[5] Sugiyono. 2010. Metode Penelitian Pendidikan Pendekatan Kuantitatif, Kualitatif, dan R \& D. Alfabeta. Bandung.

[6] SN Sirajuddin, S Nurlaelah, A Amrawaty, T Amrullah, S Rohani, IM Saleh. 2017. Relationship Between Farmers Characteristic and Income from Beef Cattle with The Traditional Profit-Sharing. American-Eurasian Journal of Sustainability Agriculture 11 (5), 29-34.

[7] SN Sirajuddin, AR Mappangaja, R Darma, I Sudirman. 2015. Value Added Analysis of Beef Cattle Supply Chain Actors Micro-Scale Community Farm Based. American-Eurasian Journal of Sustainable Agriculture 9 (7), 7-12.

[8] Kotler, P. 2009. Manajemen Pemasaran. Erlangga. Jakarta.

[9] Syafaat, N.P., Simatupang, S. Mardianto dan T. Pranaji, 2003. Konsep Pengembangan wilayah berbasis agribisnis dalam rangka pemberdayaan petani. Forum Penelitian Agro-Ekonomi, 21(1): 130-137.

[10] SN Sirajuddin, Siregar, A.R., P. Mappigau. 2017. Adoption Rate of Beef Breeders Technology Following Partnership System in Barru Regency. Department of Social Economics, Faculty of Animal Science, Hasanuddin University, Makassar. 90245. Indonesia. American-Eurasian Journal Of Sustainable Agriculture 11 (6), 31-34.

[11] Sirajuddin, Sitti Nurani, et al. 2016. "Response of cattle breeders to ricestraw silage in Soppeng Regency, South Sulawesi Province." American-Eurasian Journal of Sustainable Agriculture, vol. 10, no. 3.

[12] Sirajuddin, S.N., Nurlaelah, Abriaty. 2011. Strategi Pengembangan Ternak Kelinci di Kabupaten Soppeng. Fakultas Peternakan, Universitas Hasanuddin. Vol 2 no 1. 